\title{
Final Report for the H2Fuel Bus
}

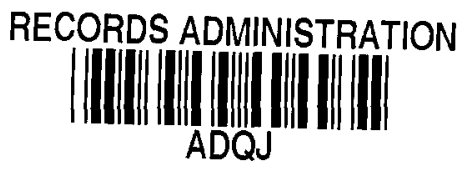

by

W. D. Jacobs

Westinghouse Savannah River Company

Savannah River Site

Aiken, South Carolina 29808

T. Motyka

L. K. Heung

W. A. Summers

DOE Contract No. DE-AC09-96SR18500

This paper was prepared in connection with work done under the above contract number with the U.S.

Department of Energy. By acceptance of this paper, the publisher and/or recipient acknowledges the U.S. Government's right to retain a nonexclusive, royalty-free license in and to any copyright covering this paper, along with the right to reproduce and to authorize others to reproduce all or part of the copyrighted paper. 


\section{DISCLAIMER}

This report was prepared as an account of work sponsored by an agency of the United States Government. Neither the United States Government nor any agency thereof, nor any of their employees, makes any warranty, express or implied, or assumes any legal liability or responsibility for the accuracy, completeness, or usefulness of any information, apparatus, product, or process disclosed, or represents that its use would not infringe privately owned rights. Reference herein to any specific commercial product, process, or service by trade name, trademark, manufacturer, or otherwise does not necessarily constitute or imply its endorsement, recommendation, or favoring by the United States Government or any agency thereof. The views and opinions of authors expressed herein do not necessarily state or reflect those of the United States Government or any agency thereof.

This report has been reproduced directly from the best available copy.

Available to DOE and DOE contractors from the Office of Scientific and Technical Information, P. O. Box 62, Oak Ridge, TN 37831; prices available from (423) 576-8401.

Available to the public from the National Technical Information Service, U. S. Department of Commerce, 5285. Port Royal Road, Springfield, VA 22161. 
WSRC-TR-98-00385

Westinghouse Savannah River Company

Savannah River Site

PO Box A

Aiken, SC 29808

\title{
Final Report for the H2Fuel Bus
}

\author{
W. D. Jacobs, L. K. Heung, T. Motyka, W. A. Summers \\ Westinghouse Savannah River Company \\ 773-A Savannah River Site, Aiken, SC 29808, USA
}

Phone: 803-725-3161, Fax: 803-725-2756, e-mail: William.Jacobs@srs.gov

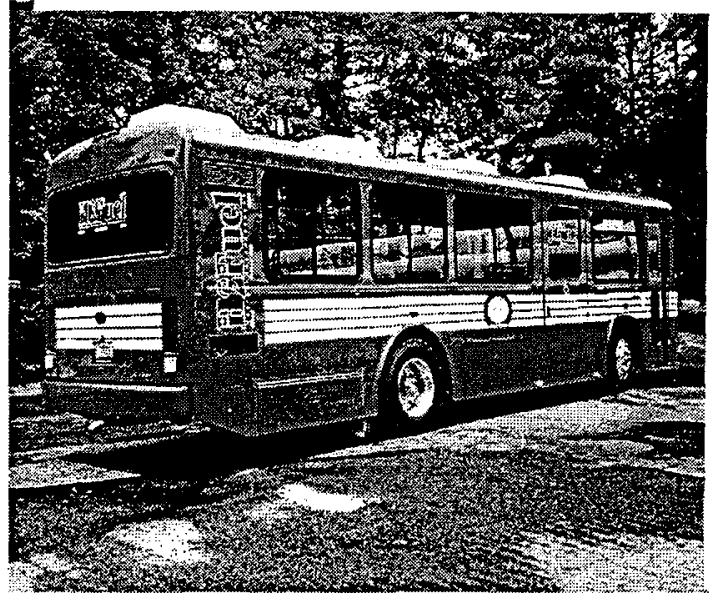

Figure 1. The H2Fuel hydrogen-powered bus

\begin{abstract}
The H2Fuel Bus is the world's first hydrogen-fueled electric hybrid transit bus (see Figure1.). It was a project developed through a public/private partnership involving several leading technological and industrial organizations, with primary funding by the Department of Energy (DOE). The primary goals of the project are to gain valuable information on the technical readiness and economic viability of hydrogen fueled buses and to enhance the public awareness and acceptance of emerging hydrogen technologies. The bus has completed its field-testing and was placed into public service on September 4, 1998 by Augusta Public Transit in Augusta, Georgia in August 1998. The bus employs a hybrid Internal Combustion (IC)
\end{abstract} engine/generator and battery powered electric drive system, with onboard storage of hydrogen in metal hydride beds. The initial operating results have demonstrated an overall energy efficiency (miles/BTU) twice the range of similar diesel-fueled bus while doubling the range of the all-electric vehicle by providing in-transit recharging of the batteries. Subsequent data has shown results that are not as promising, but still encouraging if the power plant is optimized. The project development also reduced the bus' tail-pipe emissions with NOx measured at less than $0.2 \mathrm{ppm}$. In addition to demonstrating the inherent safety of a solid-state storage system, the project also addressed permit and safety issues as a result of the safety risk assessment of the metal hydride storage system. The project also demonstrated the state-of-the-art technology in electrical system management. 


\section{INTRODUCTION}

The Savannah River Bus Project involves the development, manufacturing, and testing of the world's first hybrid hydrogen-electric transit bus, the H2Fuel Bus. The project seeks to successfully transfer technologies developed at the DOE Savannah River Site (Aiken, South Carolina) to commercial use in a public transit bus. The project is a technology verification activity to establish the technical feasibility, economic viability, and environmental benefits of hydrogen as a transportation fuel. Solution of hydrogen infrastructure issues (e.g., refueling, liability, safety, etc.), public awareness and public acceptance of hydrogen as a vehicular fuel are additional objectives. The H2Fuel Bus was developed through a partnership of federal and local governments, universities, non-profit organizations, and industry. The H2Fuel Bus is a 33-foot long, 27-passenger transit bus that was operated in the city of Augusta in passenger service. Following operations in Augusta, the Department of Energy plans to transfer the bus to the National Hydrogen Test and Demonstration Center at Nevada for use as a national test platform. Their task will include improving the technology and taking the bus to the stage of development while furthering acceptance of hydrogen.

\section{H2FUEL OVERALL SYSTEM}

Operational experience with this vehicle was centered in two major areas. The first area was determining the characteristics of operation of the metal hydride fuel storage system and the hydrogen fueled internal combustion engine (see Figure 2.). The second was the operation of the electric systems including the auxiliary power unit, batteries, battery charger/management systems, and electric drive system.

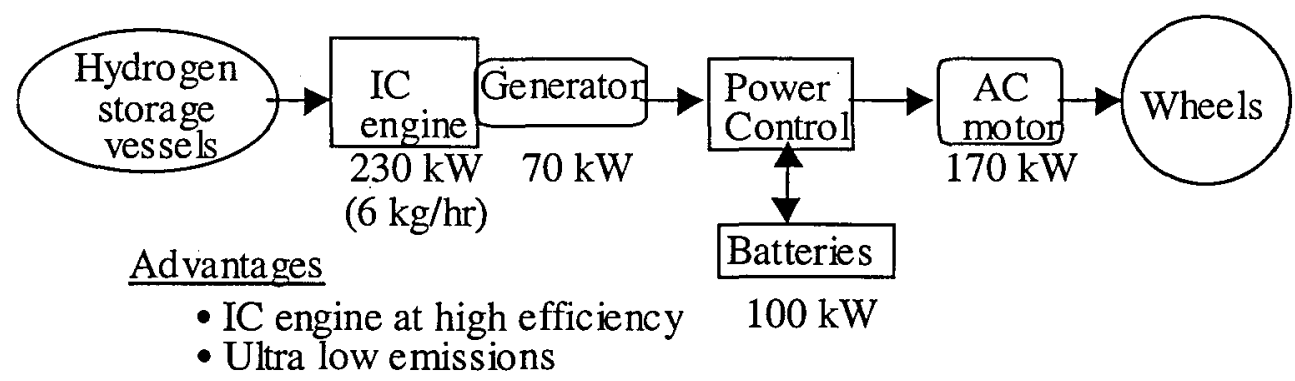

Figure 2. Schematic of the hydrogen-powered hybrid power system

\section{HYDROGEN STORAGE/INTERNAL COMBUSTION ENGINE}

The hydrogen fuel system stores hydrogen on a Lanthanum-Nickel-Aluminum (LANA) type alloy'. Metal hydrides are intermetallic compounds that undergo reversible chemical reactions with hydrogen. They absorb hydrogen when cooled and release it in a controlled manner when heated. The hydrogen is supplied to the engine by recycling the waste heat of the engine coolant system to release hydrogen from the metal alloy. The hydrogen released from the beds is regulated and then metered to the engine through a Constant Volume Injection (CVITM) unit. Hydrogen is stored on the bed at ambient temperatures and near ambient pressures.

\footnotetext{
${ }^{1} \mathrm{Lm}_{1.06} \mathrm{Ni}_{4.96} \mathrm{Al}_{0.04}(\mathrm{Lm}=\mathrm{La} 55.7 \%, \mathrm{Ce} 2.5 \%, \operatorname{Pr} 7.7 \%, \mathrm{Nd} 34.1 \%)$
} 
To utilize this system the bus required several modifications. The first conversions began with removal of two of the four original battery packs. These packs were replaced by a LANA type alloy metal hydride storage system. The metal hydride storage system was designed to occupy the same space and have approximately the same weight as the batteries removed. This system permits storage of approximately $15.2 \mathrm{~kg}$ of hydrogen. The hydride has the characteristic of 1.27 weight percent loading (approximately $6000 \mathrm{scf}$ ) at pressures less than $500 \mathrm{psig}$. This offers intrinsic safety over high-pressure systems. The system is also designed to limit hydrogen release in the event of a line break. Due to the thermodynamics of the hydrogen absorption on the hydride material, the bed cannot generate more than $74 \mathrm{scfm}$, which is approximately twice the maximum consumption rate. This rate ensures that the bed will not overpressurize in a fire scenario.

The patented hydrogen storage system consists of 24 tubes that contain the metal hydride powder (see Figure 3.). Each vessel consists of 15 chambers that are packed with aluminum foam to enhance heat transfer, a porous steel filter, and coolant channels to enhance absorption or release of the hydrogen from the metal hydride material (see Figure4.). The metal hydride material is segregated into chambers to prevent migration and damage that could result due to material swelling which results from absorption. The beds were designed to ASME standards and carry a pressure vessel rating of 500 psig.

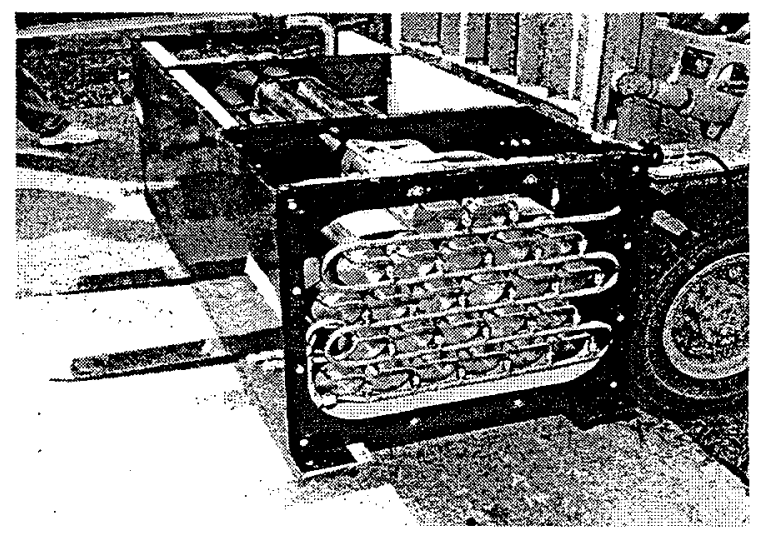

Figure 3. One of the two "boxes" containing the on-board hydrogen storage vessels.

The alloy choice was based on the engine operating temperature, expected ambient conditions, and bed temperature limits. The hydride bed temperature is the highest temperature at which the generation of hydrogen is expected during operation and the ambient condition affects the cooling water temperature used to cool the beds during refueling.

When operating at full power, the hydrogen combustion engine requires hydrogen feed rate of 6 $\mathrm{kg} / \mathrm{hr}$ at about $100 \mathrm{psig}$. pressure. At this rate, the heat required for hydrogen desorption is calculated to be $19800 \mathrm{kcal} / \mathrm{hr}$. The hydride storage system must be able to transfer this much heat from the coolant to the metal hydride during operation. The heat transfer rate for the system was enhanced by addition of aluminum foam pieces. The foam increases the heat transfer coefficient of the metal hydride bed by a factor of 5 . The heat transfer coefficient of 426 $\mathrm{kcal} / \mathrm{hr} / \mathrm{m}^{2} /{ }^{\circ} \mathrm{C}$ is more than twice the required value determined in laboratory experiments. From this result, a single box is capable of meeting the designed feed rate of $6 \mathrm{~kg} / \mathrm{hr}$. 


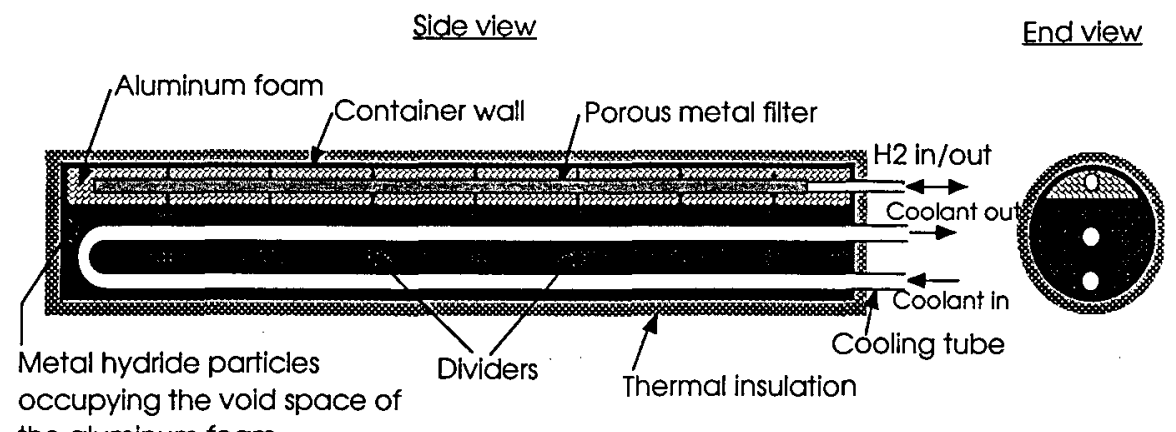

occupying the void space of

the aluminum foam

Figure 4. Schematic of the hydride hydrogen storage vessel

The Auxiliary Power Unit (APU) is a standard industrial, multi-fuel 7.5 liter V-8 internal combustion engine (Ford Model 875) with modifications including the Constant Volume Injection (CVITM) unit, heads and pistons. The $\mathrm{CVI}{ }^{T M}$ is a mechanically timed metering device timed to the intake stroke of the engine. The standard engine was modified with high compression heads and pistons, which increased the compression ratio for higher thermal efficiency. The heads have better flow characteristics to improve volumetric efficiency as well. To reduce engine knock, the exhaust from one half of the engine was cooled and recycled into the engine intake manifold. The exhaust from the other half of the engine was directed to a water separation unit and the remaining gases were passed through a three-way catalyst bed to reduce NOx emissions. To reduce the NOx emissions, the catalyst bed temperature must be limited to $130^{\circ} \mathrm{C}$; this required further modification of the engine by replacing the standard radiator with a larger, lower temperature system. In this case, a ducted fan cooling system was chosen. All of the above modifications were developed and made by Hydrogen Components Inc. $(\mathrm{HCl})$ of Littleton, Colorado, except for the cooling system, which was accomplished by Georgia Tech Research Institute. The system was optimized to reduce the engine/generator set from cycling or hunting to achieve full speed (2500 rpm).

\section{ELECTRIC SYSTEMS-}

The electrical system modifications began by removing two of the four original battery packs. Then an APU was installed. The system chosen was an AC generator whose output was rectified to match the charging voltage and current range of the existing battery system. The voltage from the APU or the batteries was inverted by the Northrup-Grumann controller system and used by an $A C$ traction motor. The system was enhanced with a regenerative braking system.

A recent modification was the addition of a BADICHEQ ${ }^{\mathrm{TM}}$ battery management system. Advantages include knowing the state of all of the cells in the system, warning of potential trouble conditions, and if needed, charging individual cells to help restore them to a normal state. Preliminary testing of the battery system indicated that problems due to deep cycling and thermal overheating of the batteries caused some cells to fail prematurely. Discussions with the battery manufacturer and the bus manufacturer led to the installation of the BADICHEQ ${ }^{\text {TM }}$ system. Temperature compensation of the off-board charging system was also installed. After collecting data for several runs, the various manufacturers were consulted to adjust the operating parameters. 
The BADICHEQTMsystem has several interlocks, which are designed to prevent overcharging the batteries, or causing damage due to operation in conditions that have not been reviewed. The first interlock requires that both battery packs be installed before the APU is permitted to operate. This prevents dumping excess current into only one pack and stressing the batteries. Similarly, the second interlock will not permit the regenerative braking feature to be used when the APU is operating, since the APU/regenerative braking combination has the potential to overcharge the batteries.

A recent modification made by the Enerpro battery charger manufacturer has been the development of a circuit board that will permit the BADICHEQ ${ }^{\text {rMto }}$ control the battery charging profile dynamically. This allows for optimum charging and protection of the batteries. This project was under development too late to be incorporated into the H2Fuel Bus, but should be considered for future projects.

Currently, the battery charging is conducted from a static profile determined from the manufacturer of the batteries and the charger. The only dynamic feature of the system is that it is temperature compensated and will shutdown the charger if the pack temperatures exceed $50^{\circ} \mathrm{C}$. This has had limitations. The charger must see both temperature probes before it will allow a charging profile to begin. If one probe fails, the temperature compensation must be bypassed to allow the charger to function. A failed probe in November of 1997 resulted in bypassing the temperature compensation. Combined with a failing battery, it resulted in over charging a battery to the point that it became a resistive heat load and heated the pack to $65^{\circ} \mathrm{C}$ (as monitored by the BADICHEQ'Ththermistor for the pack).

The history of the battery packs has been one of deep discharges and poor thermal management. This left the packs in less than optimum condition before the BADICHEQTM installation. Since the BADICHEQ ${ }^{\mathrm{M}}$ monitoring has begun, most thermal management issues are corrected, except for a battery that fails (most failures provide sufficient warning to permit scheduled replacement without damage occurring to adjacent batteries). And, the BADICHEQ ${ }^{\mathrm{TM}}$ system has allowed for better diagnostics and maintenance of the remaining batteries in the packs. It has greatly aided the diagnosis and changeout of failing batteries. At the current time, one battery has failed and one or more are severely degraded, indicating that battery replacement is a priority to assure successful future operation. The battery manufacturer, the BADICHEQ ${ }^{\text {TM }}$ representatives and Blue Bird Bus Company, has also recommended this.

\section{DISCUSSION OF RESULTS}

The bus was operated for 1003 miles total. Three hundred miles were operated in the Augusta, GA area. The bus was tested in a variety of conditions from the flat inner city, to the steep grade, to highway conditions. It had good operating characteristics in all situations.

Some modification to the basic motor controller software was made to compensate for the two battery packs that were removed. The bus tended to limit its available power to the traction motor if the demand exceeded the available power. This limitation was most pronounced on the steep grade and usually at lower battery pack voltages. Another option to controlling this condition was to start and operate the APU prior to arriving at the grade.

When battery life became an issue, it was decided to operate the APU in a constant run mode rather than the original on-off mode of operation. This preserved battery lifetime, but reduced the efficiency and overall availability of the APU (2-4 hours of constant APU operation versus the expected 8 hours of intermittent operation). 
After a number of test runs, the bus entered passenger service September 3,1998 . The bus was operated for two days in service and then removed from transit duty for preparation to transport to Nevada.

\section{CONCLUSIONS}

Hydrogen System-

1) The hydrogen fuel storage system has performed better than expected. The initial estimates for hydrogen capacity were around $15.2 \mathrm{~kg}$ or $1.27 \mathrm{wt} . \%$. In actual refueling and operating conditions, the bus was found to hold more hydrogen than expected. This increase in storage capacity for the given conditions is currently under investigation in laboratory bench-scale testing at SRTC to better understand the phenomenon.

\section{Electrical System-}

2) The engine/generator efficiency is limited by the Northrup-Grumann controller's ability to direct power. A review of the data available indicates that the APU is capable of generating $70 \mathrm{~kW}$ (nameplate rating). However, the output of the APU is only $9 \mathrm{~kW}$ avg. (20 kW peak). This is less than 30 percent as efficient as anticipated or an overall engine efficiency of $\sim 10$ percent.

Data shows that the bus motor consumes $28.3 \mathrm{kWh}$ avg. (90.3 kWh peak). Power seems to be preferentially drawn from the batteries rather than the generator output under present conditions. The previous data from initial bus operations (where the batteries were deeply discharged) created a greater demand signal and increased generator output and hence its fuel economy. The initial data shows that the design objective of an efficiency twice that of a conventional diesel bus have been achieved, but it now remains for the project to improve battery life while maintaining generator efficiency.

The generator set can provide only a portion of the running power under normal operating conditions, while maintaining good battery operating practices. The bus' range could be significantly increased if this condition is optimized.

3) The bus consumed $2.63 \mathrm{kWh} / \mathrm{mi}$. on average $(15.70 \mathrm{kWh} / \mathrm{mi}$. peak). This consumption is higher than the original projection of $1.53 \mathrm{kWh} / \mathrm{mi}$. It is believed that the difference is due to the APU not being optimized with the power controller system.

4) The APU consumption rates measured to date are $67 \mathrm{scf} / \mathrm{mile}$ and $49 \mathrm{scfm}$ at $100 \%$ load. The resulting range numbers are 30 miles in all-electric mode and approximately 80 miles in the hybrid mode.

5) The record of 89 miles in one trip (batteries charged and full hydrogen fuel load) was not representative of actual performance that should be expected. The mileage covered was at the expense of battery life. The batteries were severely deep discharged and damage resulted. The result was an eventual replacement of 10 batteries and shortened lifetimes for all batteries. At the time of this report, 14 batteries have been replaced over the life of the packs and two are at or near failure in the passenger pack. 


\section{RECOMMENDATIONS}

Based on the performance observed, the following recommendations would be made to the next generation vehicle:

Hydrogen Storage -

1) The ultimate capacity of the bed should be investigated by conducting isotherm data for the hydride bed material along with determining its other characteristics.

2) Improving the hydrogen refueling times will require study of the cyclic nature of the hydrogen absorption. The cyclic pattern may be the result of a flow limiter restricting hydrogen flow. The loading of hydride beds plumbed in series represents an area for improvement. Currently heat is transferred from the loading bed to the other bed in the system. Also, the coolant for the beds does not circulate simply through the beds, but mixes with the balance of the bus' coolant system.

3) The amount of hydrogen desorbed from the bed (hence engine runtime) is limited by the pressure/temperature of the hydride beds. It may be possible to adjust the cooling configuration of the exhaust gas to the catalyst bed to permit higher engine operating temperatures, without affecting the NOx emissions.

Auxiliary Power Unit -

1) The APU performs as intended, but work on increasing the fuel efficiency should continue. The consumption of hydrogen by the engine changes only $20 \%$ between full load and idle conditions.

2) Optimize the Northrup-Grumann controller to increase load demand signal to the generator output and preferentially draw power from the generator (if available). This may change the operating scheme from continuously running the engine to shutting off the engine and operating for period of time in the all-electric mode.

Regenerative Braking -

1) The regenerative braking system should be investigated. This system designed by Northrup-Grumann performs as intended, but it has the capability to overcharge the batteries and damage them if the braking is applied too fast and the current to the battery packs is not limited. For this reason, the regenerative braking has been temporarily disabled.

2) The best recommendation for correcting this shortcoming is to investigate the use of an energy buffer such as an ultracapacitor bank. It offers the ability to quickly store charge and then meter it to the system at the normal voltage without damage to the batteries. It also has the benefit that it conforms to space requirements and can be scaled to voltage requirements of an existing system.

Batteries -

1) The battery system was not initially optimized and battery pack instability reduced the life of 15 batteries. The new battery management systems have alerted operators to potential problems so planned work outages could be taken. 
2) The batteries are a system that will require upgrading. The batteries that are currently used do not have the cycle life required for a transit vehicle. Also, the cost of the batteries is high. There appears to be some promising work by a battery manufacturer which is working with Neocon that will more than double the cycle life and reduce the cost by one fourth. Alternatives to the Horizon ${ }^{\mathrm{TM}}$ batteries should be evaluated.

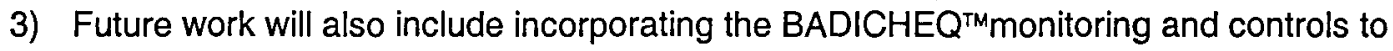
replace the off-board charger control, creating a dynamic charge profile.

4) The same BADICHEQ ${ }^{r m}$ control modification should be incorporated into the APU operation and regenerative braking systems (post-ultra capacitors).

5) A full compliment of new batteries should be purchased and installed, since the useful lifetime of remaining batteries is questionable and since the effort to replace individual batteries is labor intensive. Also, the replacement of individual batteries tends to unbalance the pack more than having all new batteries in place.

Miscellaneous -

1) The electric wiring of the bus should be reviewed for compliance to National Electric Codes and Standards and corrections made to any deficiencies found.

2) The Data Acquisition System (DAS) should be modified to provide a "fuel" gauge

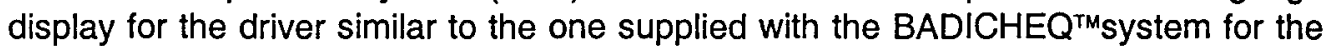
batteries. This will ensure the driver has full awareness as to the energy reserves onboard.

3) The DAS should be redesigned to make it more rugged for thermal and vibration conditions expected in normal service and all programs should be ported and run from one computer. All ports and connectors should be standardized.

4) All of the sensors onboard should be standardized to a common signal format if possible. This will simplify future modifications and testing.

5) All power supplies should be standardized to $12 \mathrm{vdc}$ as supplied by the bus' electrical system.

6) Offboard 120-vac electric power should be provided to the bus and outlets supplied within the cabin area to support maintenance.

7) A 120-vac to 12-vdc rectifier should be placed onboard to allow operation of all installed instruments and equipment, without requiring the startup of the bus or the APU. 


\section{ACKNOWLEDGEMENTS}

Georgia Tech Research Institute - Hybrid bus design, integration and testing

Augusta Richmond County Public Transit - Owner/operator

Blue Bird Bus Co.-Electric bus manufacturer

Hydrogen Components Inc. - Hydride vessel construction, engine conversions

Southeastern Technology Center; Education Research and Development Association of Georgia Universities; Air Products and Chemicals, Inc.; Energy Research and Generation, Inc.; Power Technology Southeast, Inc.; Northup-Grumman Corp.; Air Liquide America Corp.; Electrosource, Inc.; Neocon Technologies, Inc.; Enerpro, Inc.

This paper was prepared in connection with work done under Contract No. DE-AC0996SR18500 with the U. S. Department of Energy.

\section{REFERENCES}

1) WSRC-MS-98-00470, "Performance Testing of a Hydrogen-Fueled Electric Hybrid City Transit Bus," W. D. Jacobs, L. K. Heung, T. Motyka, W. A. Summers.

2) Heung, L. K., (1988), "Heat Transfer and Kinetics of a Metal Hydride Reactor," MetalHydrogen Systems, vol. II, 1451-1461, Edited by R. Kirchheim, E. Fromm, and E Wiche, Stuttgart, Germany.

3) Heung, L. K., (1997), "On-board Hydrogen Storage System Using Metal Hydride," HYPOTHESIS II Conference held at Grimstad - Norway, August 18-22, 1997.

\section{DEFINITIONS, ACRONYMS, ABBREVIATIONS}

APU - Auxiliary Power Unit

BADICHEQ ${ }^{\mathrm{TM}}$ - Battery Diagnosis and Checking

$\mathrm{CVI}^{\mathrm{TM}}$ - Constant Volume Injection

DAS - Data Acquisition System

IC - Internal Combustion

LANA- Lanthanum Nickel Aluminum Alloy

NOx - Nitrogen Oxides 


\section{TIMELINE OF AUGUSTA OPERATIONS}

March 30, 1997 -

April 3, 1997 -

April 11, 1997 -

April 16, 1997 -

April 17, $1997-$

April 22, 1997 -

April 24, 1997 -

May 15, $1997-$

May 22, 1997 -

June 9, 1997 -

July 2, 1997 -

July $14,1997-$

July $15,1997-$

July $26,1997-$

July 1997 -

August 26, 1997 -

September 2, 1997 -

September 23, 1997 -

October 1, 1997 -

October 3, 1997 -

October 5, 1997 -

October 7, 1997 -

October $9,1997-$
Bus arrived in Augusta, GA

First $\mathrm{H} 2$ refueling operation in Augusta, $250 \mathrm{psig}$

Bus weighed on official scales, 28300 empty weight with full load of fuel

Bus batteries recharged

Bus operated 33.5 hours for 7 miles

Public Bus Dedication Ceremony (Sen. Sam Nunn-GA, Mario Fiori-DOESR, Ambrose Schwalle- WSRC, Augusta Mayor Larry Sconyers)

Excess flow valve problem noted

Bus consumption per Frank Lynch 1850 STD I/min at 2500 rpm

Test run, 40 miles

Generator common jumper replaced

Bus refueled, identified pump prime problem and corrected

Completed record 89 miles, total mileage to date is 725 miles

Refueled $4735 \mathrm{scf} \mathrm{H} 2$ at $270 \mathrm{psig}$

Generator electrical short in rectifier unit

New 500 psig ASME pressure relief valve sized

Rectifier/generator rebuilds completed by WSRC and inspected by GTRI

Blue Bird Bus Company repaired the battery packs and replaced one bad battery

Generator rebuild complete (diodes, fusing, wiring, voltage regulator)

The engine/generator set was reconnected

The battery packs were returned from Blue Bird and installed in the bus

The Power measurements Limited ACM-3300 power monitor was returned from the manufacturer (no problems noted)

Completed modifications to the Enerpro charger - replaced EPROM with new one that has charge profile tailored for the Horizon batteries and installed temperature compensation

Enerpro battery charger upgraded to provide temperature compensation 
October 14,1997 - Load tested generator after rebuild - no problems noted. Identified a SCSI communication problem in the computer.

October 21, 1997 - Identified a low pack voltage problem in passenger side battery pack

October 22, 1997 - Refueled the bus with 2295 scf H2 ( 1300 scf passenger side and $\sim 1000$ scf driver side), was able to identify a bad battery in the passenger side battery pack

November 17,1997 - Dr. Swain, University of Miami came to take measurements of the underbody of the bus for his leak simulation.

November 24, 1997 - Helium leak testing conducted by Dr. Swain, University of Miami, to model effects of hydrogen leak under the bus. Initial results indicated the bus was safe and no significant amount could collect.

December 3,1997 - Battery replacements initiated, Advantech DAS computer sent out for repairs.

December 15, 1997 - Ron Satchell, Northrup-Grumann, made software modifications to the motor controller and verified operation; the modifications helped adjust torque limiting at lower pack voltages due to only two packs being used versus the original design of four.

Driver battery pack removed and broken down. Testing showed three had failed, two had a low voltage, and one had a bad Radsock connector that indicated arcing had occurred.

Passenger pack had no bad batteries identified, but three had a low voltage.

December 18, 1997 - Rebuilt the battery packs with the aid of Chris Morris, Electrosource.

Neocon Technologies representatives made inspection of the bus for bid proposal on a BADICHEQTM installation.

December 29, 1997 - The glass partition was installed in the back of the bus to safeguard data acquisition system.

January 1998 - $\quad$ BADICHEQTM installed.

January 30, 1998 - Noted the battery charger would not work; identified the problem as a bad temperature-sensing probe in the passenger side pack. Disconnected probe to finish charging.

Conducted an APU run.

February 6, 1998 - Conducted an APU test run. Bus traveled 32.5 miles.

February 17, 1998 - Identified battery problems in the passenger side battery pack. Replaced three bad batteries and reinstalled.

February 25, $1998-\quad$ Advantech computer reinstalled without necessary RS-485 repairs. 
Refueled the bus with a total of 2945 scf H2 (Passenger side -1310 scf, Driver side $-1635 \mathrm{scf}$ ).

$\mathrm{H} 2$ sensors calibrated at the factory and returned to service.

March 3,1998 - National Hydrogen Conference, Washington, D.C., bus was used in public demonstration rides for 200 passengers (Congressional, industry, and media representatives), and 75 public school children. The bus completed 5 runs totaling 40 miles during these demonstration runs.

March 26, 1998 - Hydride beds removed from the bus for replacement of pressure relief valves with ASME code approved ones.

April 22, 1998 - $\quad$ Advantech computer returned from factory and RS-485 communication problem corrected; factory did not indicate nature of the problem. Work was completed under warranty.

Pressure relief valve work on the beds themselves is completed and the beds returned to the bus.

May 14, 1998 - The passenger side battery pack would not energize. Identified a problem with the Kilovac relay. Replaced relay and problem cleared.

Sent Enerpro battery charger circuit board off for repair due to data not being collected.

Refueled bus

May 19, $1998-$

Detected a small hydrogen leak on the new pressure relief valves. The leak was at a threaded union.

Conducted an all-electric mode run to test and cycle the batteries. Run was 8.2 miles in 47 minutes.

Identified two bad batteries the \#3 in the passenger side, and the \#26 in the driver side packs.

Removed hydride beds from bus.

May 26, 1998 -

Completed leak tests on resealed pressure relief valves and reinstalled on the beds.

May 27, $1998-$

Hydride beds installed in bus.

June 3, 1998 -

Passenger battery pack refurbished with three used batteries from the driver pack. Three new batteries installed in the driver pack. Installed temperature sensor in passenger pack.

June 4, 1998 -

Enerpro charger circuit board returned and problem was identified as a failed temperature probe. Ordered replacement probes.

June 9,1998 -

Ordered four replacement batteries based on results of BADICHEQ ${ }^{\mathrm{TM}}$, three for driver side and one from passenger side. 
June 30,1998 -

July 7,1998 -

July 10, 1998 -

July $23,1998-$

July $24,1998-$

July 30, 1998 -

August 5, $1998-$

August 11, 1998 -

August $19,1998-$

August 25, 1998 -

September 4, 1998 -

September 9, $1998-$
July 21,1998 -

Driver side BADICHEQ ${ }^{\mathrm{TM}}$ damaged during rebuilding the battery pack. Unit was sent back to Neocon Technologies.

Neocon repaired and returned a faulty optical isolator (factory problem).

Damaged BADICHEQ ${ }^{\text {TM }}$ repaired and returned to service. Driver side battery pack installed.

Conducted a 2-hour run and covered 30 miles. Engine shut down due to high temperature (note: record high temperatures).

Bus refueled with a total of $10537 \mathrm{scf} \mathrm{H} 2$ (passenger side $-7282 \mathrm{scf}$, driver side $-3255 \mathrm{scf})$.

Ran APU for 0.25 hours

Data acquisition for the SCXI system transferred onto a laptop.

\section{Ran APU for 1.25 hours}

Bus would not start due to failed speed switch. Determined it was not a necessary interlock and jumpered out.

Data communication ACM-3300 established.

Refueled bus with a total of 4964 scf H2 (passenger side -2498 scf, driver side -2470 scf).

Operated the bus for 7.2 miles, used 1081 scf H2 (150 scf H2/mile).

Detected potential problem with battery \#3 in passenger pack, which terminated run.

Hydrogen leak detectors alarmed due to weather change and high humidity. Recalibrated sensors.

Initial passenger run in fare service - traveled 20.4 miles and carried 18 passengers, one driver, and two support personnel. Consumed 4869 scf $\mathrm{H} 2$.

Second passenger run in fare service - traveled 18.2 miles and carried 14 passengers. The run consumed $1580 \mathrm{scf}$ of $\mathrm{H} 2$ in 30 minutes. The total distance covered was 15 miles.

Passenger side battery pack indicated fault condition - battery \# 3 failing.

September 11, 1998 - New ACM-3300 power monitor installed.

September 15, 1998 - Unsuccessful data run, cause unknown.

September 17, 1998 - Final test run.

October 22, 1998 - $\quad$ Bus transferred to DOE-Nevada Operations. 


\section{Attachment 1}

\section{Metal Hydride Bed Design Data}

Metal Hydride Alloy $\mathrm{Lm}_{x} \mathrm{Ni}_{(5-y)} \mathrm{Al}_{y}$

$\mathrm{Lm}$ is lanthanum-rich mischmetal

$x=1.05 \pm 0.01, y=0.03$

Anneal: $975^{\circ} \mathrm{C}, 12$ hours, inert atmosphere

Hydrogen desorption pressure: 13.2 atma at $60^{\circ} \mathrm{C}$ Desorption plateau slope $\Delta(\ln P) / \Delta(H / M): 0.26$ at $60^{\circ} \mathrm{C}$

Hydrogen capacity $\Delta \mathrm{H} / \mathrm{M}: 0.86$ at $40^{\circ} \mathrm{C}$

Form: -10 mesh particles of crushed alloy

Hydride Storage Vessel:

Metal hydride: $26.6 \mathrm{~kg}$

Cylindrical: 3.5" 0D, 60" long, 0.065" thick walls Twelve chambers

316L stainless steel

10-micron sintered metal tube filters for hydrogen

U-shaped tubes for heating/cooling liquid

Maximum working pressure: 750 psig

Pressure relief through top of bus
Fuel Containers:

Two

24 vessels each (48 total vessels)

Combustible gas detection in each container

Vent through top of bus

Hydride Storage System:

Total weight: $\leq 5000 \mathrm{lb}$

Hydride weight: $\approx 1280 \mathrm{~kg}(2816 \mathrm{lb}$.)

Hydrogen capacity: $\geq 12 \mathrm{~kg}$

Required hydrogen purity: $\geq 99.99 \%$

Hydrogen pressure: $\geq 2$ atm-idle; $\geq 6$ atm-full speed Hydrogen pressure/flow sufficient to start engine at $0^{\circ} \mathrm{C}$

Refueling conditions:

Ambient temperatures $\left(\approx 25^{\circ} \mathrm{C}\right)$

H2 pressure: $\approx 100 \mathrm{psi}(<500 \mathrm{psi})$

Time: $\leq 8$ hours 


\section{Attachment 2}

\section{Expected Performance}

- Range

- Fuel Consumption

- Speed

-Acceleration

- Gradability

- Emissions

- $\mathrm{CO}_{\mathrm{x}}$

- $\quad \mathrm{NO}_{x}$
$>100 \mathrm{mi}$.

$\sim 6 \mathrm{KgH}_{2} / \mathrm{hr}-40 \mathrm{scf} / \mathrm{min}$

0 to $55 \mathrm{mph}$

$0-30 \mathrm{mph}$ in $20 \mathrm{sec}$

start on $12 \%$ grade

Near 0

$\leq 0.1 \mathrm{~g} / \mathrm{bhp}-\mathrm{hr}$ 


\section{Attachment 3}

\section{Initial Test Data}

\begin{tabular}{|c|c|c|c|c|c|c|c|c|c|}
\hline Date & 16-Apr & 18-Apr & 22-Apr & 23-Apr & 24-29-Apr & 22-May & 3-Jun & 17-Jun & 26-Jun \\
\hline Hubometer & (odo) 173. & 268.10 & 309.6 & 352.8 & $439-481$ & 481.5 & 534.4 & 609.5 & 679.1 \\
\hline Total miles & 45 & 41.8 & 39.6 & 86.5 & 42 & 39.6 & 38.8 & 63.4 & 38.7 \\
\hline miles-Battery & 16 & 2.8 & 18.8 & 31.3 & $(10-20)$ & 9.9 & 18.6 & 12.1 & 4.3 \\
\hline$\underline{\text { miles-H2 }}$ & 29 & 39.1 & 20.8 & 55.2 & $(22-32)$ & 29.7 & 20.2 & 51.3 & 34.4 \\
\hline Engine run (min) & 63 & 57 & 82 & 114 & $(-)$ & 28 & 75 & 107 & 10 \\
\hline$\underline{\text { Refueled- scf }}$ & 1099 & 1837 & 3646 & 3367 & 1692 & 1174 & 853 & 2341 & 4735 \\
\hline scfímile & 37.9 & 47.0 & 175.3 & 61.0 & 48.3 & 39.5 & 42.3 & 45.6 & 137.6 \\
\hline scf/minute & 17.4 & 32.2 & 44.5 & 29.5 & - & 41.9 & 11.4 & 21.9 & 52.6 \\
\hline Miles/ engine min. & 0.46 & 0.69 & 0.25 & 0.48 & $\ldots$ & 1.06 & 0.27 & 0.48 & 0.38 \\
\hline \multicolumn{10}{|l|}{ Efficiency H2/Diesel } \\
\hline \multicolumn{10}{|c|}{ Air Liquide Records } \\
\hline Date & 17-Apr & 21-Apr & 22-Apr & $23-A p r$ & 25-Apr & 29-Apr & 2-Jun & 4-Jun & 25/26-Jun \\
\hline Hiah Temp. (F) & 70 & 84 & 82 & 67 & 74 & 66 & & & 5 \\
\hline scf & 1099 & 1837 & 3646 & 3367 & 915 & 777 & 1174 & 853 & 2341 \\
\hline
\end{tabular}




\section{Attachment 4}

\section{Transit Day Log}

The bus was operated on the streets in transit conditions the following days (note this is a partial listing and DAS data files do not exist for all dates):

\begin{tabular}{|l|l|}
\hline January 30,1998 & June 1, 1998 \\
\hline February 4, 1998 & June 2, 1998 \\
\hline February 5, 1998 & June 8, 1998 \\
\hline February 6, 1998 & June 9, 1998 \\
\hline February 10, 1998 & June 29, 1998 \\
\hline February 12,1998 & July 10, 1998 \\
\hline February 18, 1998 & July 21, 1998 \\
\hline February 24, 1998 & July 23, 1998 \\
\hline February 25, 1998 & August 18, 1998 \\
\hline March 3, 1998 (Washington, D. C.) & August 20, 1998 \\
\hline March 4, 1998 (Washington, D. C.) & August 21, 1998 \\
\hline March 5, 1998 (Washington, D. C.) & September 1, 1998 \\
\hline March 31, 1998 & September 3, 1998 \\
\hline May 7, 1998 & September 9, 1998 \\
\hline May 8, 1998 & September 17, 1998 \\
\hline May 29, 1998 & \\
\hline
\end{tabular}

Detailed printout of the technical data collected will not be provided here, but will be archived on computer media. 